\title{
Poetry and Music in Ancient Iran
}

\author{
Seddigheh Akbari \\ Pre_Islamic History Department \\ Islamic Azad University (Science \& Research Branch), Tehran, Iran \\ Tel: 98-91-2275-5626, 98-91-9828-0312 E-mail: sara_pasargad5835@yahoo.com
}

Received: January 19, 2011 Accepted: March 24, 2011 doi:10.5539/ass.v7n7p239

\begin{abstract}
This article is dealing with the question of the relation between poem \& music Pre_Islamic Time. No doubt Iran is famous for its poetry in the whole word, and a great number of 2500 poets are already known to have a book.

Not withstanding we have not very many written heritage from those glorious period. The main cause of cause is frequent assault by the foreigners since Islamic Era which have normally ended in ruin \& disruptions of almost every ancient Remainees. But, despite all sad events, we could find out many eternal Remembrances from Zoroastrian Avesta (mostly its Gatha: Gahan) and flourishing extravagant court of Khosrow Parviz. Right at the end of Sassanid Dynasty.
\end{abstract}

Keywords: Poetry, Music, Ancient Iran, Barbad, Royal Court

\section{Introduction}

Literature of Iran has special status at history literature of the world. From the oldest time at this land many Iranian by creating beautiful and valuable works have enriched the civilization of this land. Pre-Islamic period there was verses and prose in both religious and non-religious works, so far the subject of these texts demonstrate a kind of diversity but all of them show the figures of speech.Works including Asourik Tree, Report Card of Ardeshir Babakan, Cities of Iran shahr, Khosro Ghavdan and, Ridak, Bondeheshn and dinkart at different sections with social, historical, geographical and religious topics are among great literary works. At Islamic time this excellent series of works were continued. In spite that during first century literature was faced with depression but during Samanid era the rulers seriously supported and observed value for Persian literature and language. After Samanid the literature of Iran was entered into serious stage and the rulers, kings and different classes of the society observed special status for Persian literature. Emergence of great men including Naser Khosro, Ferdowsi, Sadi, Molavai, Hafiz globalized the fame and popularity of Persian literature. These narrations are related of course to the written literature of this. From social point of view it can be said that most of these poets based on their taste selected a poetic style and social grounds of their time in which poems and issues against kings, kingships governments or corruption of kings were less seen in their works. Poets did not directly mention to corruption of kings and their governments; of course not mentioning corruption of kings and their government did not indicate that the poets were ahached to the courts. Some of these poets by using symbolic language referred to the realities and social problems. Mentioning realities of society within the framework of animals stories is among the most considerable samples one of the excellent works in this field is the Mouse \& the Cat by Obeid Zakani. In fact it can be said that understanding social status of Iran from written literature had been a difficult job and in most cases many people did not observe the notices. But besides written texts, the oral literature of Iran was among the inseparable part of public culture of the society. History had played an important role for mentioning and transferring inner emotions, spiritualities and events. Explicitness of statement, mentioning utterances, using more from sarcasm language, satire and irony, being understandable by the public are among the main characteristics of this type of literature which indicates social characteristic of it. One of the main groups that played again and important role on transferring emotions of people and narrating public culture and history were minstrels. The main idea of minstrels was their important relationship with both the government and the people. Their method of narration was accompanied with song and music resulted enthusiasm in the whole societies from the ordinary men up to aristocrats. Samanid period is regarded as the end of ancient minstrelsy art in Iranian literature. Then oral literature which was completely public and not related to governments was less accompanied with music, In fact oral literature introduced Iran with satire, sarcasm and even scrutiny language. (Khaleghi Motlagh, 1991) 


\section{Poetry in Ancient Iran}

In order to answer this question that whether before the Arab domination Muslims there were poetry in Iran, there us an issue of discussion for many the surveys which conducted research about the culture and language of Iran. Some researchers believe that poetry is only limited to public and elementary songs (Najm Abadi, 1976). Finally upon the discovery of Manerid texts in Tourfan ended to discussion in relation to poetry of Iran before Islam, since these texts were completely compatible with poem characteristics. In spite that these poems have great differences with poems of Islamic Iran but their rhythmic characteristic by insisting on syllables indicate type of poem but the main discussion is that what type of poem it is and what is its concept? We believe that the best comment in this relation is narration of Abbas Eghbal. In short Eghbal defines concept and meaning of poem as word of poem is not Arabic rather it is Arabicized and it is originated from Arabic language which means song and anthem and surely poem was accompanied with music. In the past most poets indicate framework of each part and they had beautiful voice and they welcomed playing harp; they were going to the courts the kings and they sang song while playing harp (Eghbal, 1984). This rhythmic characteristic of poem accompanied with music and song resulted in creation of so-called minstrelsy in Ancient Iran. The supreme point of success of these artists was Sasanid period and therefore in terms of middle Persian the term minstrel (Khonyagar) or Honyagar has been created since Sasanid period. In spite the terms including Navagar, Rameshgar and Chamehgo are seen in Pahlavi texts, but none of them had the meaning of minstrel and as we know the term poet is an Arabic popularized after Islam and is not discriminated from minstrel but what does minstrelsy mean! Before Noldke and then Christensen would conduct the researches in relation to the concept of this term, among last western researchers by using Iranian and non-Iranian resources one of the most considerable researches was conduct by Mary Boyce. In Iran Saeed Nafisi has had a short reference, Zabihollah Safa and $\mathrm{m}$. Ghazvini have not offer much information to us. Mehrdad Bahar in his works has offered some valuable issues in scattered mode. Meanwhile Abbas Eghbal upon conducting research with regard to poetry of Iran has offered interesting issues. Even Ehsan Yarshater in the Cambridge history has offered valuable ideas in relation to the history of Iran had not dealt with this issue. Others have offered some issues in relation to poem in ancient Iran but Jalal Khaleghi Motlagh has suggested a text with the title of Ancient Epic in which by using western resources dominating epic of Iran he had successfully fulfilled the job. Dr. Khaleghi Motlagh in relation to peddler poets and their working method has mentioned that they went from place to place and by uttering song and music sang epics This group was found even amongst the German and French tribes (Khaleghi Motlagh, Ibid.1991) These people did not have high social respect in west and from view of westerners were named beggar, cruel, prudent, impolite, and clown which most people did not like to communicate with them. But in Iran in accordance with the method of ancient era, minstrels had rather suitable and social status among the people and courtiers (Ibid.). Not only minstrels in Iran transferred epic narrations among public but also entertained the people by song and music. It is indicated from evidences that the best minstrel who had had a good memory, nice voice and mode proficiency on musical instrument and different type of songs could enter to the court and then they would receive high social status so they would be considered as the servant of the kings and had some type of political and social advantages (Ibid.). As we can see Astiages minstrel is regarded as an important political event within the framework of story for minstrel (Gousan) sang song for king .In fact there were two groups of minstrels including the first that entertained public people and the second who entered to the court and showed their art for to courtiers. The evidences are available in ancient Iran are mainly those related to the second group.

\section{Minstrelsy at Achaemend \& Parthian time}

Evidences including books of the Greece historian indicate that many years before the Sasanids minstrels had social respect among the kings. Denyom narrated that one of the great minstrels during Medes read many poems and songs in favor of Astiages and then he read a special poem in which he mentioned to very powerful wild animal found in swamp and dominated over a zone and when Astinages asked from the kind of the wild animal the poet referred to the name of Cyrus the grate. In writings of xenofon it was referred to stories accompanied with songs during Achaemenid period (Bozorg Alavi, 1978). In relation to minstrels during Parthian it might be said that their social structure did not paid less enough attention to written literature in comparison to Achaemenid and Sasanid. Now most of the researchers believe that the work remained from Zariran and Asourik tree both were changed and belonged to Parthian period (Behzad Bashi, 1989 p.45) Parthians greatly paid attention to oral literature. During this period poets by playing music with song showed their art which is called Gousan. Evidences indicate that Gousan played important role in the life of Parthians. As we had already mentioned they both entertained court and public and also there are some evidences from written texts in which according to their and social structure we can understand the value of oral literature among them. Parthian period 
or Pahlevanied is famous with heroism of kings and great commanders of the time together with the traditions of heroes. Parthians were supporter of territorial and political integrity of Iran in front of the enemies in North and East and on the other hand they revived noble Iranian traditions in culture and arts. In traditions of heroes they had great attention to epics and epic literature was not supported, except they were peddler poets who are among main supporters and transferers of this type of literature. Sasanids upon futile attempts intended to eliminate Parthians from national the history of Iran and seemingly were succeeded, but Gousan influenced Sasanid system in which Sasani kings had very good relation with minstrels and minstrelsy and heroism traditions which was among indicators of Parthian period were never forgotten and even they were revived by some Sasanid poets.

\section{Minstrelsy during Sasanid Period}

Information availed and resources whit relation to minstrels during Sasanid is greater than Parthid. Existence of minstrels including Sarkash, Barbad and Nakisa specially Barbad fat the court of Khosro Parviz, existence of several songs as to the number of days and months during Sasanid (Eghbal, p.8) legend of bringing Lourian to Iran by Bahram Gour for entertaining people (Ferdowsi, Shahnameh, p.451) and evidences in Shahnameh by ferdowsi (Ibid.) indicate excellent role of minstrels in which flourishing period of minstrelsy in Iran was during Sasanid period. In spite that written literature in this time in comparison to other periods of ancient Iran has a great growth, meanwhile oral literature and history were highly attended by Sasanids. The thing that has achieved from the epics in fact is regarding the great deal of attention of Sasanid to the national history of Iran.

\section{References}

Boyce Mary. (1989). Asourik Tree. Translated by Mahiyar Navabi. Agah publications, Tehran.

Boyce Mary. Vis \& Ramin, translated by Behzad Bashi.Agah publications, Tehran S.D

Boyce Mary. (1996). Yadgar zariran translated by Behzad Bashi Agah publication, Tehran.

Brown Edvard. Literary History of Iran. Volume 1 S.D.

Christansen. A.E. (1997). Poem \& Music in Iran. Translated by Abbas Eghbal. Homa publication Institute, Tehran.

Eghbal abbas. (1998). Poem and Music in Iran, Tehran.

Ferdowsi Abbolghasem. (1939). Shahnameh, Moscow, first edition, volume 7, Tehran.

Khaleghi Molagh Jalal. Ancient Epic, S.D.

Noldke Teodor. (1978). National Epic of Iran. Translated by Bozorg Alavi, Tehran.

Satari Jalal. (1991). Grounds \& Culture of people, first Edition, Virastar publication, Tehran.

Tavadiya. (1976). Language \& Literature of Pahlavi (Middle Persian), translated by S.Najm Abadi, The University of Tehran. 